\title{
PROTOTIPE SISTEM INFORMASI PENDAFTARAN PESERTA PEKAN OLAHRAGA PROVINSI BALI
}

\author{
Agus Aan Jiwa Permana ${ }^{1)}$ Ni Putu Dwi Sucita Dartini ${ }^{2)}$ \\ Manajemen Informatika ${ }^{1)}$ \\ Fakultas Teknik dan Kejuruan, Undiksha, Singaraja/Bali \\ Pendidikan Jasmani, Kesehatan, dan Rekreasi ${ }^{2)}$ \\ Fakultas Olahraga dan Kesehatan, Undiksha, Singaraja/Bali \\ agus.aan@undiksha.ac.id ${ }^{1)}$ sucita.dartini@undiksha.ac.id ${ }^{2)}$
}

\begin{abstract}
With the progress of information, data exchange can run more easily because there are many facilities for sharing data. One of them is by email and website. By utilizing the website, the registration process can be done online and the registration process can be done easily from anywhere. In addition, data collection can also be done easily, making it suitable for use in the registration process for participants in the provincial sports week (Porprov) especially in Bali. Porprov Bali in its implementation process in Singaraja yesterday still collected athletes data using excel files, both in the process of distributing and recording the data. So that it will take a lot of time to recapitulate the athlete's data, then a lot of time will be needed to collect back-up files for the committee from branch managers from all districts in Bali. Based on the explanation, the authors collaborated with colleagues in the physical and sports education department to develop a database for online Porprov. This study have produced a program prototype to register.
\end{abstract}

Keywords: data sharing, Athlete Registration, Porprov Bali

ABSTRAK
Dengan kemajuan informasi, pertukaran data dapat berjalan lebih mudah karena terdapat banyak fasilitas untuk melakukan sharing data seperti dengan email dan website. Proses pendaftaran berbasis web dapat dilakukan secara online dan proses pendaftaran dapat dilakukan dengan mudah dari manapun. Selain itu pengumpulan data juga dapat dilakukan dengan mudah, sehingga cocok untuk digunakan untuk pendaftaran peserta pekan olahraga provinsi (Porprov) khususnya di Bali. Porprov Bali dalam proses pelaksanaanya di Singaraja kemarin masih mengupulkan data atlet menggunakan file excel, baik dalam proses penyebaran dan perekapan datanya. Sehingga akan menghabiskan banyak waktu untuk merekap data atlet, kemudian banyak waktu yang dibutuhkan untuk mengumpulkan berkas kempali kepada panitia dari pengurus cabang dari semua kabupaten di Bali. Berdasarkan paparan tersebut, penulis melakukan kerjasama dengan rekan di jurusan pendidikan jasmani dan keolahragaan untuk mengembangkan sebuah pendafdataran untuk altet Porprov berbasis online. Hasil penelitian ini sudah menghasilkan sebuah prototipe program untuk melakukan pendaftaran.

Katakunci: data saring, Pendaftaran Atlet, Porprov Bali

\section{PENDAHULUAN}

Saat ini proses sharing data sudah tidak asing lagi di masyarakat Sehingga berbagai macam format data sudah dapat di sharing melalui berbagai macam media secara online. Situssitus pemerintah dan organisasi sekarang dengan mudah dapat diakses secara online. Berdasarkan wawancara dengan rekan panitia Porprov Bali saat di Singaraja, dikatakan bahwa proses pendaftaran atlet ke Porprov cukup panjang. Proses berawal dari pengiriman formulir pendaftaran secara offline dari panitia pelaksana porprov kepada koni kabupaten/kota yang sampai akhir pendistribusiannya sangat panjang dan konvensional. Konvensional yang dimaksud adalah berkas berpindah dari tangan ke tangan. Perpindahan data manual (Non Electronik Data Interchange) berakibat tidak tercatatnya rekam jejak data awal sampai akhir proses seleksi. Belum lagi data bisa hilang. Proses perpindahan data secara elektronik (Electronik Data Interchange) dapat dilakukan dengan bantuan teknologi informasi. Apalagi untuk sekedar membawa berkas dari kabupaten menuju provinsi membutuhkan waktu, tenaga, dan biaya.

Walaupun sistem lama masih berjalan, namun perlu terjadi pencatatan data secara elektronik untuk mengetahui perjalanan berkas yang dibawa dari sumber ke tujuan akhir. Sehingga berdasarkan pertimbangan 
ini perlu dikembangkan sebuah sistem yang dapat membantu proses perpindahan berkas saat pendaftaran peserta Porprov Bali sehingga proses menjadi lebih efektif dan efisien. Selain itu rekam jejak berkas juga dapat diketahui dengan jelas.

Berdasarkan hal tersebut perlu dikembangkan sebuah rancang bangun sistem dan mengimplementasikan sistem untuk dapat membantu pendaftaran atlet Porprov. Adapun manfaat yang diharapkan dalam penelitian ini adalah :

1.Hasil penelitian ini diharapkan dapat memberikan sumbangan perpaduan pemikirian dengan menghasilkan produk dalam bidang olahraga dengan bantuan teknologi informasi.

2.Dengan adanya sistem diharapkan mampu membantu proses pendaftaran atlet Porprov Bali, sehingga proses dapat berjalan secara efektif dan efisien.

3.Penelitian ini diharapkan dapat menambah wawasan dan pengetahuanbagi peneliti yang berguna dalam penciptaan produk atau karya-karya ilmiah yang semakin berkualitas serta bermanfaat di masa mendatang.

\section{TINJAUAN PUSTAKA}

\section{Penelitian Terkait}

Dalam memfokuskan penelitian ini, telah diperoleh beberapa sumber yang terkait dengan penelitian yang sedang dilaksanakan seperti Tabel 1.

Tabel 1. State of The Art

\begin{tabular}{|l|l|l|}
\hline No. & $\begin{array}{l}\text { Penulis } \\
\text { (Tahun) }\end{array}$ & Deskripsi \\
\hline 1 & $\begin{array}{l}\text { Yoda, dkk } \\
\text { (2016) }\end{array}$ & $\begin{array}{l}\text { Adapun tujuan dari } \\
\text { penelitian ini } \\
\text { mendeskripsikan } \\
\text { tanggapan atlet } \\
\text { terhadap program } \\
\text { pelatihan } \\
\text { kondisi fisik dan } \\
\text { implementasinya pada } \\
\text { persiapkan atlet } \\
\text { Buleleng pada } \\
\text { porprov serta tingkat } \\
\text { kondisi fisik atlet } \\
\text { Buleleng dalam } \\
\text { Porprov Bali XII } \\
\text { tahun 2015 }\end{array}$ \\
\hline 2 & $\begin{array}{l}\text { Efendi dan } \\
\text { Pramono(2 } \\
016)\end{array}$ & $\begin{array}{l}\text { Adapun tujuan dari } \\
\text { penelitian ini } \\
\text { menggambarkan } \\
\text { kecemasan Atlet } \\
\text { Hockey Putra Gresik } \\
\text { sebelum bertanding. }\end{array}$ \\
\hline
\end{tabular}

\begin{tabular}{|l|l|l|}
\hline & & $\begin{array}{l}\text { Metode penelitian } \\
\text { yang digunakan } \\
\text { dalam penelitian ini } \\
\text { adalah metode } \\
\text { deskriptif kuantitaif }\end{array}$ \\
\hline 3 & $\begin{array}{l}\text { Marianza } \\
\text { (2016) }\end{array}$ & $\begin{array}{l}\text { Adapun tujuan dari } \\
\text { penelitian ini } \\
\text { Mendeskripsikan } \\
\text { peranan, } \\
\text { menganalisis faktor } \\
\text { pendukung dan } \\
\text { penghambat, serta } \\
\text { upaya yang dilakukan } \\
\text { Disdikpora Dalam } \\
\text { Porprov Tahun 2015 } \\
\text { di Kota Lubuklinggau }\end{array}$ \\
\hline 4 & $\begin{array}{l}\text { Muslihudi } \\
\text { a dan } \\
\text { Samopa } \\
\text { Larasati } \\
\text { (2014) }\end{array}$ & $\begin{array}{l}\text { Hasil penelitian ini } \\
\text { dapat dijadikan bahan } \\
\text { pertimbangan bagi } \\
\text { panitia penerimaan } \\
\text { mahasiswa baru di } \\
\text { Stmik Pringsewu } \\
\text { Lampung. }\end{array}$ \\
\hline 5 & $\begin{array}{l}\text { Fandatiar, } \\
\text { dkk., 2015 } \\
\text { prototipe sistem } \\
\text { informasi pendidikan } \\
\text { dan pelatihan berbasis } \\
\text { web yang dapat } \\
\text { digunakan untuk } \\
\text { melakukan proses } \\
\text { automasi pendaftaran } \\
\text { serta administrasi } \\
\text { hasil diklat yang telah } \\
\text { dilaksanakan }\end{array}$ \\
\hline $\begin{array}{l}\text { Hangun ini adalah } \\
\text { sebuah sistem } \\
\text { informasi yang } \\
\text { digunakan untuk } \\
\text { pengelolaan kegiatan } \\
\text { KKN, manfaat sistem } \\
\text { informasi KKN ini } \\
\text { diharapkan dapat } \\
\text { meningkatkan } \\
\text { pelayanan dalam } \\
\text { pengelolaan kegiatan } \\
\text { KKN serta } \\
\text { memperlancar proses } \\
\text { administrasi kegiatan } \\
\text { KKN menjadi lebih } \\
\text { akuat dan }\end{array}$ \\
\hline
\end{tabular}

Sistem Informasi 
Sebelum membahas sistem lebih jauh lagi, sebaiknya perlu diketahui apa sebenarnya sistem informasi tersebut lebih dulu, berdasarkan sumber yang berhasil dikutip terdapat beberapa pengertian antara lain.

Bonni dan Marion (2008), mengatakan bahwa sistem informasi adalah rangkaian komponen yang terdiri dari manusia, prosedur, data, dan teknologi untuk memprosesnya menghasilkan informasi.

Sehingga sistem informasi dapat digunakan untuk mengambil keputusan (Erporate, 2017).

Tujuan sistem informasi adalah

Memproses data menjadi informasi untuk digunakan dalam proses pengambilan keputusan (Kirana, 2017).

Berdasarkan paparan diatas, penulis dapat mengartikan bahwa sistem informasi sebagai sarana dalam bentuk perangkat lunak untuk mengolah data menjadi informasi untuk pengambilan keputusan serta bermanfaat untuk organisasi (Permana, 2017).

\section{Pekan Olahraga Provinsi (Porprov)}

Dalam perjalanannya Porprov, diawali dengan diadakannya Pekan Olahraga Nasional (PON) tahun 1946 yang kemudian menyatukan dua buah lembaga yaitu Persatuan Olahraga Republik Indonesia (PORI) dengan Komite Olimpiade Republik Indonesia (KORI) menjadi Komite Olahraga Nasional Indonesia (KONI). KONI bertugas mempersiapkan atlet untuk mengikuti kejuaran di tingkat nasional maupun internasional.

(Anonim, 2016).

Kota Solo sebagai kota penyelenggara Pekan Olahraga Nasional pertama kalinya pada tanggal 9 sampai dengan 12 September tahun 1948 silam. Selain itu Sejarah PON

kali pertama memberikan dampak yang samgat baik karena walaupun wilayah Indonesia dipersempit dengan perjanjian Renville tetap dapat membuktikan kepada dunia bahwa masih memiliki semangat olahraga yang positif.

Kemudian cabang KONI di masingmasing provinsi menyelenggarakan Porprov dengan tujuan menjaring putra-putri terbaik daerah untuk mewakili daerahnya di ajang PON.

Porprov dilaksanakan 2 (dua) tahun sekali (Marianza, 2016). Ketua umum KONI Bali, I Ketut Suwandi mempertangdingkan 34 cabang olahraga untuk persiapan PON 2020 yang rencana diselenggarakan di Gianyar, kemudian 2019 akan dilaksanakan di Tabanan (Baliberkarya, 2017).

\section{Website}

Dalam proses untuk online, sistem yang dikembangkan harus berbasiskan web atau lengkapnya website. Website adalah sekumpulan halaman yang dibuat dengan format HTML. HTML kepanjangan dari Hypertext Markup Language dengan perpaduan link dan text (Andre, 2017).

Dalam perkembangannya web dapat bersifat statis berubah menjadi dinamis dengan bantuan basis data. Basis data yang digunakan untuk menyimpan data secara online adalah basis data client server. Menurut (Rahmadani, 2013) Basis Data Client Server adalah cara distribusi dari clien ke server dengan data terpusat yang dikendalikan server. Server melayani permintaan dari worstation yang melakukan permintaan ke server.

\section{Pengujian Sistem}

Pengujian sistem menggunakan metode black box yang berfokus pada persyaratan fungsional perangkat lunak. Dengan demikian, pengujian black box terfokus pada sisi fungsional perangkat lunak (Mustaqbal, dkk. 2015).

Black Box Testing cenderung untuk menemukan hal-hal berikut:

- Fungsi yang tidak sesuai.

- Masalah antarmuka (interface errors).

- Masalah pada struktur data dan akses basis data.

- Masalah performansi (performance errors).

- Salah inisialisasi dan terminasi.

Pengujian didesain untuk menjawab pertanyaanpertanyaan berikut:

- Fungsi-fungsi diuji agar supaya dapat dinyatakan valid.

- Input yang baik

- Apakah sistem sensitif pada input tertentu?

- Bagaimana data dapat diisolasi?

- Berapa banyak rerata data dan jumlah data yang dapat ditangani sistem?

- Efek yang dapat membuat kombinasi data ditangani spesifik pada operasi sistem 


\section{METODOLOGI PENELITIAN}

\section{Metode Research and Development} (R\&D)

Alfindasari (2014) mengatakan bahwa Pada dasarnya penelitian R\&D memiliki karakteristik adanya produk yang dihasilkan dari penelitiannya. Produk yang dihasilkan ini diawali dari analisis kebutuhan dari lokasi penelitian. Secara umum, model R\&D telah dikembangkan oleh beberapa ahli salah satunya model yang dikembangkan oleh Bolt and gall yang mengembangkan model R\&D melalui beberapa tahapan, yakni seperti Gambar 1 .

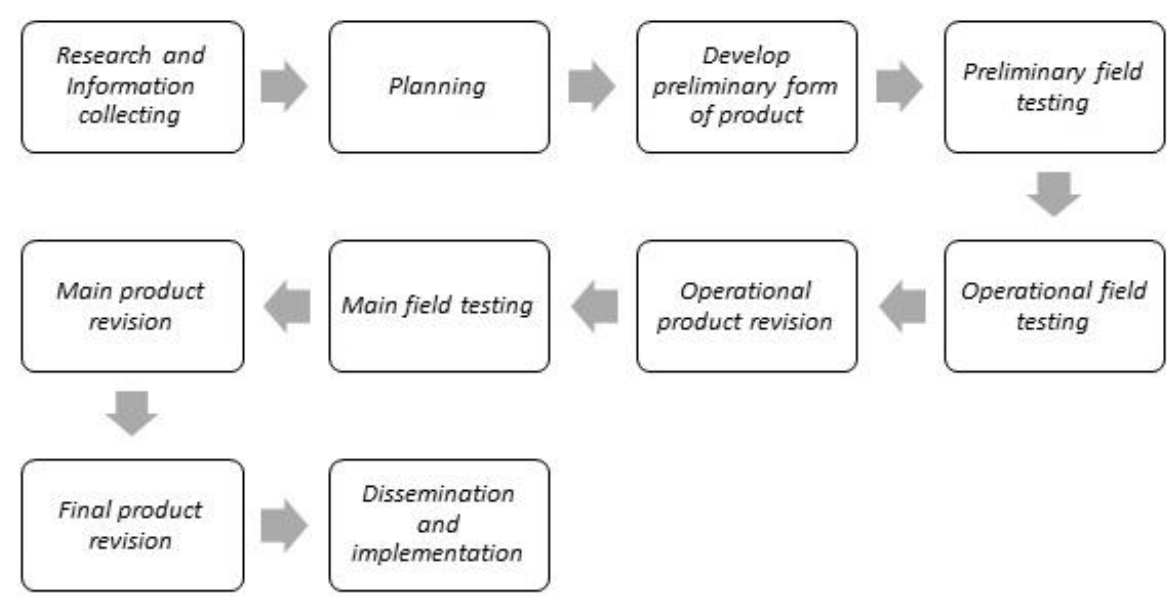

Gambar 1. Tahapan Metode R\&D

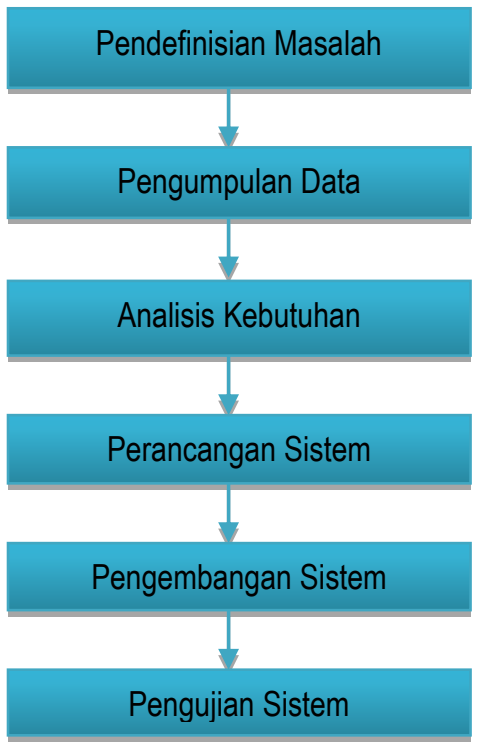

Gambar 2. Tahapan SDLC Waterfall

Tahapan Pengembangan Sistem

Metode pengembangan sistem adalah System Development Live Cycle (SDLC) berbasis waterfall. SDLC merupakan metodologi pengembangan perangkat lunak yang digunakan dalam beberapa teknik dan 
bidang industri seperti rekayasa sistem, perangkat lunak, teknik mesin, dan ilmu komputer. Model waterfall memiliki tahapan yang mengalir ke bawah (Bassil, 2012). Adapun tahapan-tahapan pengembangan sistem yang akan dilaksanakan terlihat pada Gambar 2.

\section{Metode Pengumpulan Data}

a. Observasi, dengan mengamati langsung mengamati ke lapangan

b. Wawancara, langsung dengan panitia pendaftaran Porprov

c. Serta kajian pustaka atau studi literatur, membaca berbagai buku, makalah dan bahan bacaan lain sebagai referensi yang dapat dijadikan acuan untuk pengembangan sistem. Selain itu data dan informasi yang di butuhkan juga diperoleh dengan mengunjungi berbagai situs-situs terkait yang menyediakan berbagai informasi yang relevan dengan bahasan penelitian

Lokasi Penelitian

Adapun pemilihan lokasi penelitian adalah di FOK sebagai uji sistem dengan skala kecil adalah karena para dosen dan mahasiswa FOK terlibat langsung pada Porprov Bali. Sehingga memudahkan untuk melakukan pengujian sistem dan apabila terjadi ketidaksesuaian dengan di lapangan segera dapat direvisi lagi.

\section{HASIL DAN PEMBAHASAN}

Hasil dari penelitian ini adalah sebuah prototipe website pendaftaran Porprov Bali berbasis online seperti pada Gambar 2. Pengembangan website ini akan terus berlanjut sampai pada tahap pengujian dalam situasi real seperti pelaksanaan Porprov di Tabanan. Namun pengembangan situs memerlukan waktu dan biaya. Sehingga nantinya website benar-benar dapat dimanfaatkan oleh atlet serta panitia untuk menjaring peserta secara lebih obyektif lagi.

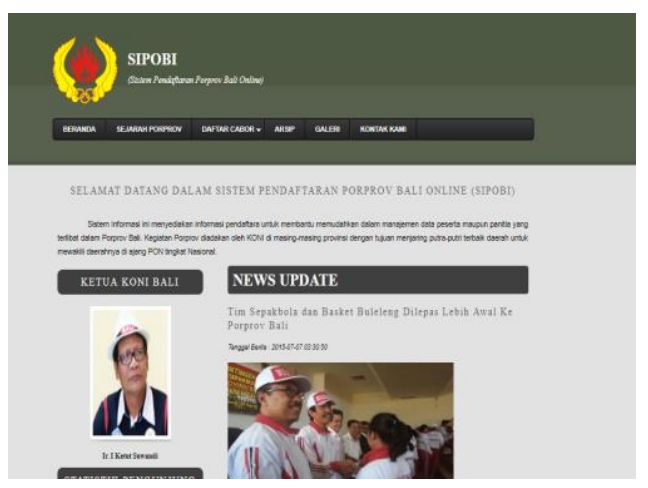

Gambar 3. Halaman Depan Website

\section{SIMPULAN}

Dengan menerapkan metode $R \& D$ dan SDLC dalam mengembangkan sistem. Secara umum sistem sudah berhasil dikembangkan walaupun dalam bentuk prototipe. Hal ini menjadi tantangan tersendiri untuk pengembang untuk mengembangkan sistem sampai pada tahap implementasi dan pengujian secara riil. Proses pengembangan sistem sudah sampai pada proses pendaftaran peserta Porprov. Harapan ke depannya adalah sistem ini benar-benar menjadi jempatan antara peserta dan panitia Porprov.

\section{DAFTAR PUSTAKA}

[1.] Anonim, 2016, Sejarah PON untuk Pertama Kalinya di Indonesia Lengkap Juara Umum Sampai Tahun 2016, http://www.penemuanterbaru.com/201 6/09/sejarah-pon.html

[2.] Alfindasari, Dessy. 2014. Langkahlangkah Melakukan R\&D (Research and

Development),http://www.eurekapendi dikan.com/2014/12/karakteristik-rresearch-and-development.html

[3.] Bonnie S. dan Marion P. 2008. Designing Information System, Jakarta: Elex Media Komputindo

[4.] Erporate, 2017. Sistem informasi, http://erporate.com/sistem-informasi/

[5.] Efendi, H. dan Pramono, M., 2016. Kajian Kecemasan Atlet Hockey

Putra Kabupaten Gresik Sebelum Bertanding di Porprov Jawa Timur V Tahun 2015, Jurnal Kesehatan Olahraga Vol 6. Nomor 02 Edisi Oktober Tahun 2016 halaman 5-10

[6.] Fandatiar, G., Supriyono, Nugraha, F., 2015. Rancang Bangun

Sistem Informasi Kuliah Kerja Nyata (Kkn) Pada Universitas Muria

Kudus, Jurnal SIMETRIS, Vol 6 No 1 April 2015, ISSN: 2252-4983

[7.] Gerhaantara, R. dan Samopa, F. 2013. Pembuatan Sistem Informasi

Pendidikan dan Pelatihan dalam Jabatan Berbasis Web pada Bagian Pengembangan Pegawai Direktorat Jenderal Perbendaharaan, Jurnal Teknik Pomits Vol. 2, No. 2, (2013) ISSN: 2337-3539 
[8.] Marianza, Y. 2016. Evaluasi Kinerja Dinas Pemuda Dan Olahraga Kota Lubuklinggau Dalam Penyelenggaraan Kegiatan Pekan Olahraga Provins! (Porprov) Tahun 2015 di Kota Lubuklinggau, Program Magister, Universitas Terbuka

[9.] Muslihudin, M., dan Larasati, A., 2014. Perancangan Sistem

Aplikasi Penerimaan Mahasiswa Baru Di Stmik Pringsewu Menggunakan Php Dan Mysql, Jurnal TAM (Technology Acceptance Model) Volume Desember 2014, Vol. 30, No. 1, Juni 2013

[10.] Trapsiladi, P. 2013. Pengembangan Sistem Informasi Laboratorium Berbasis Web Dalam Rangka Peningkatan Kinerja Pelayanan Jasa Pengujian Industri Kerajinan Dan Batik, Dinamika Kerajinan Batik

[11.] Yoda, I.K, Sudiana, I.K, Peling, S.W.Y. 2016. Evaluasi Program Pelatihan Kondisi Fisik Atlet Buleleng Pada Porprov. Bali Xii Tahun 2015, Jurnal Penjakora Undiksha Vol 3, No 1 , https://ejournal.undiksha.ac.id/index.ph p/PENJAKORA/article/view/11665 